\title{
НАУЧНО-ПРАКТИЧЕСКАЯ КОНФЕРЕНЦИЯ «ОБРАЗОВАТЕЛЬНЫЙ ТУРИЗМ КАК ВАЖНЫЙ КОМПОНЕНТ И ФАКТОР ПОВЫШЕНИЯ КАЧЕСТВА УЧЕБНОГО ПРОЦЕССА В ШКОЛЕ И ВУЗЕ» (7 апреля 2016 г., г. Москва)
}

\author{
Ю. С. Путрик \\ (Московский гуманитарный университет)
}

Аннотация: В статье описывается опыт работы спортивнобального клуба «Латинский Квартал Реутов» (2. Реутов, Московская область), в котором занятия бально-спортивными танцами проводятся под внешним и внутренним педагогическим контролем.

Ключевые слова: Московский гуманитарный университет; обзор; туризм; образовательный туризм

\section{RESEARCH-TO-PRACTICE CONFERENCE “EDUCATIONAL \\ TOURISM AS A CRUCIAL COMPONENT AND A FACTOR IN IMPROVING QUALITY OF TEACHING AT SCHOOL AND IN UNIVERSITY" (Moscow, April 7, 2016)}

\author{
Yu. S. Putrik \\ (Moscow University for the Humanities)
}

Abstract: This is a short review of research-to-practice conference "Educational tourism as a crucial component and a factor in improving quality of teaching at school and in university" which was held at Moscow University for the Humanities on April 7, 2016.

Keywords: Moscow University for the Humanities; review; tourism; educational tourism

7 апреля 2016 г. в Московском гуманитарном университете (МосГУ) в рамках Международного студенческого форума состоялась научнопрактическая конференция на тему «Образовательный туризм как важный компонент и фактор повышения качества учебного процесса в школе и вузе». Конференция была организована факультетом международных отношений и туризма МосГУ совместно с Российским НИИ культурного и природного наследия им. Д. С. Лихачева и Международной Туристской Академией (МТА). С приветственным словом к собравшимся обратилась доктор педагогических наук, профессор, Л. В. Романюк, проректор по научной работе МосГУ. 


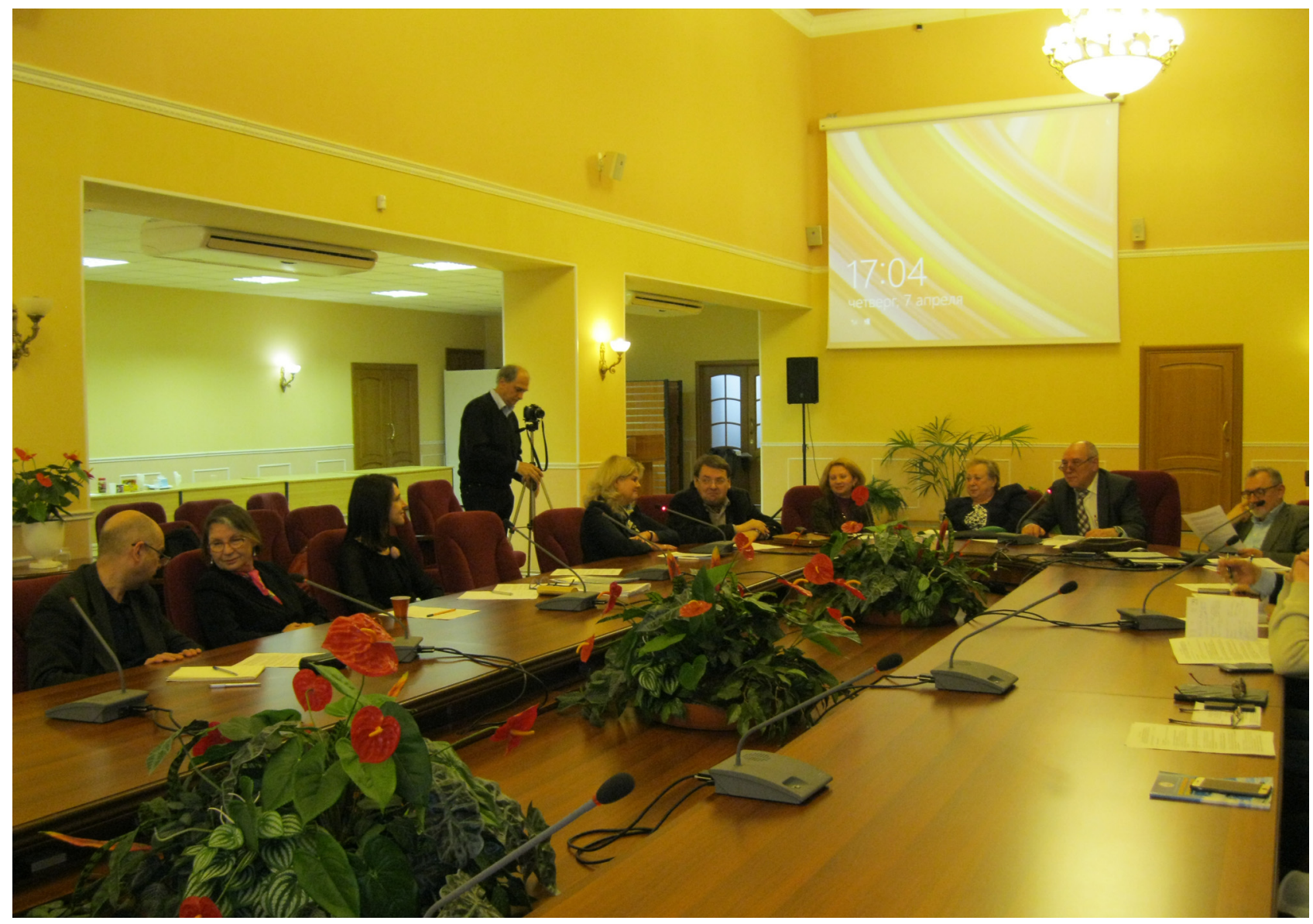

В ходе конференции были заслушаны и обсуждены доклады представителей научного и бизнес сообщества по актуальным вопросам повышения роли туризма, туристских и экскурсионных технологий в системе российского образования. В работе конференции приняли участие более 40 человек. С докладом выступила декан факультета международных отношений и туризма МосГУ, доктор философских наук, профессор Г. П. Хорина. В своем выступлении раскрыла роль образовательного туризма как фактора успешной модернизации образовательного процесса в России, показала имеющиеся и пока неиспользуемые резервы этого вида деятельности. Доктор исторических наук, заведующий кафедрой социальнокультурного сервиса и туризма МосГУ Ю. С. Путрик подробно остановился на вопросах институализации образовательного туризма и необходимости более широкого включения туристского метода при подготовке и реализации государственных образовательных стандартов.

Президент МТА, кандидат культурологии С. Ю. Житенёв осветил проблемы использования культурно-исторического наследия как базового ресурса образовательного туризма. Аспекты взаимодействия образовательной и туристской сфер всесторонне и на конкретных примерах продемонстрировала А. Ю. Александрова, действительный член МТА, профессор МГУ им. М. В. Ломоносова. В её докладе были раскрыты причины 
и формы взаимодействия образования и туризма, а также результаты их синергии, а также освещен вклад тематических парков в развитие теории и методов активного обучения, показаны возможности использования педагогических технологий в продвижении туристских продуктов.

С зарубежным опытомобразовательных поездок студентов как важного компонента профессиональной подготовки работников туристской сферы, участники конференции ознакомились благодаря докладу профессора кафедры технологий в туристической индустрии Белорусского государственного университета физической культуры В.В.Дворниченко. Действительный член МТА, кандидат философских наук, доцент Московского государственного университета дизайна и технологий В. П. Титов представил всесторонний анализ современного образовательного туризма в России, интересно рассказал об инновационных процессах в этой сфере и необходимости разработки современной концепции его организации, исследования эффективных методов менеджмента и маркетинга образовательного туризма. А. И. Сесёлкин, член Президиума МТА, профессор РГСУ уделил внимание развитию образовательного туризма в связи с проблемами оздоровления молодежи.

Несколько докладов и выступлений было посвящено вопросам развития образовательного туризма как составной части учебновоспитательного процесса в вузах России. Особое внимание было уделено вопросам патриотического воспитания школьников и молодежи средствами туризма и экскурсий, что отразилось в статьях студентов и преподавателей Южно-Уральского государственного университета (г. Челябинск). Рассмотрены формы и методы применения туристских и экскурсионных технологий как средства и метода урочной и внеурочной деятельности в рамках различных уровней образовательных программ в школах, средних организациях профессионального образования и в вузах.

По результатам работы конференции издан сборник материалов. В нем содержатся научные статьи большинства участников данной конференции по тематике представленных ими докладов в очном и заочном формате.

Путрик Юрий Степанович - доктор исторических наук, заведующий кафедрой социально-культурного сервиса и туризма Московского гуманитарного университета, вице-президент Международной Туристской Академии. Адрес: 111395, Россия, г. Москва, ул. Юности, д. 5. Тел.: +7 (499) 374-79-56. Эл. адрес: putrik@list.ru 
Putrik Yurii Stepanovich, Doctor of History, Chair, Department of Sociocultural service and tourism, Moscow University for the Humanities; VicePresident, International Academy of Tourism. Postal address: 5 Yunosti St., 111395 Moscow, Russian Federation. Tel.:+7 (499) 374-79-56. Email: putrik@ list.ru 